\title{
DFIG-Based WT System Using FPWM Inverter
}

\author{
Habib Benbouhenni*, Zinelaabidine Boudjema**, Abdelkader Belaidi* \\ *National Polytechnique School of Oran Maurice Audin, Oran, Algeria \\ ** Electrical Engineering Departement, Faculty of Technology, Hassiba Benbouali University, Chlef, Algeria. \\ (habib0264@gmail.com, boudjemaa1983@yahoo.fr,belaidiaek@gmail.com) \\ $\$$ Corresponding Author; Habib Benbouhenni, BP: 50B Ouled Fares Chlef, Algeria, Tel: +213663956329, \\ habib0264@gmail.com
}

Received: 30.06.2018 Accepted:02.09.2018

\begin{abstract}
In this work, we present a comparative study between fuzzy pulse width modulation (FPWM) and classical PWM technique in indirect vector command (IVC) of stator reactive power and stator active energy command of a doubly fed induction generator (DFIG) based wind turbine system (WTS). The obtained results showed that, the IVC using FPWM technique have current with low total harmonic distortion (THD) and more minimum electromagnetic torque ripple, stator reactive and stator active powers ripples then conventional PWM strategy.
\end{abstract}

Keywords DFIG, pulse width modulation, fuzzy pulse width modulation, indirect vector command, stator reactive power, stator active power.

\section{Introduction}

Traditionally the PWM strategy is generally used in changeable speed drive of AC machine [1]. This technique is easy to realize and simple modulation scheme. On the other hand, the PWM technique gives more total harmonic distortion (THD). To solve the disadvantages of PWM method of AC machine, various modulation techniques have been proposed. Space vector modulation method (SVM) [2, 3]. Selective harmonic elimination strategy (SHEPWM) [4, 5]. Third harmonic injection PWM [6, 7]. Discontinuous pulse width modulation (DPWM) commands scheme [8]. Inverted sine carrier pulse width modulation (ISCPWM) method [9]. These modulation strategies are used in order to improve the performance of the power electronic circuit, minimize the size, lower cost and increase reliability [9]. In this article, we propose new PWM technique based on the fuzzy logic regulator (FPWM). This proposed modulation is simple modulation scheme, easy to realize and give more and more minimum THD of current compared with the classical PWM strategy.

Since DFIG that are one of the largely accepted types of WTS [10]. The rotor of the DFIG is related to AC-DC-AC converter and the stator is coupled to the power grid. However, various command strategies have been proposed for studying the behaviour of DFIG based WTS during normal operation [11]. In [12], a direct torque command (DTC) was proposed to regulate the rotor flux and torque. In [13], a direct power command method based on hybrid artificial intelligent command with SVM strategy. In [14], a field oriented command for grid-associated DFIG. In [15], a sliding mode command (SMC) was proposed to command stator reactive and stator active energy of a doubly fed induction generator. In [16], backstepping command was designed to command stator reactive and active powers. In [13] vector command is the largely accepted method used to command the stator active and stator reactive powers of a DFIG machine based wind energy conversion system.

In this work, we apply the indirect vector command (IVC) to the WTS of a $1.5 \mathrm{MW}$ DFIG with the modulation scheme identified as FPWM method and compared with the classical PWM scheme.

\section{FPWM Inverter}

The PWM inverter has been accepted in the area of power electronics and drive systems. The main objective of the PWM technique is to command the inverter output voltage and to reduce the harmonic in the output voltage. Fig. 1 shows the principle of the PWM technique of the twolevel inverter. 
Since fuzzy logic (FL) is known as the universal approximators and have several applications in command design and identification [17]. Zadeh first introduced the fuzzy set theory in 1965 [18]. However, this technique is able to use human reasoning, not in terms of discrete symbols and numbers, but in terms of fuzzy sets. These terms are quite flexible with respect to the definition and values [19]. To obtain high-performance DFIG machine a robust and simple indirect vector command based on the fuzzy pulse width modulation (FPWM) technique is designed to command and regulate the stator reactive power and stator active power. On the other hand, indirect vector command with FPWM inverter (IVC-FPWM) have many advantages, reducing the powers ripples, gives more and more minimum THD value of stator current, simple rule base, simple command and robustness against disturbances.
For the proposed FSVM in Fig. 2, the universes of discourses are first partitioned into the seven linguistic changes NB, NM, NS, EZ, PS, PM, PB. The FL controller contains three blocks: fuzzification, fuzzy rule base and defuzzification.

The block diagram of FL regulator based hysteresis comparator is shown in Fig. 3. The membership function definition for the input changes "Error in comparators hysteresis" and "Change in Error of comparators hysteresis" is given by Fig. 4 .

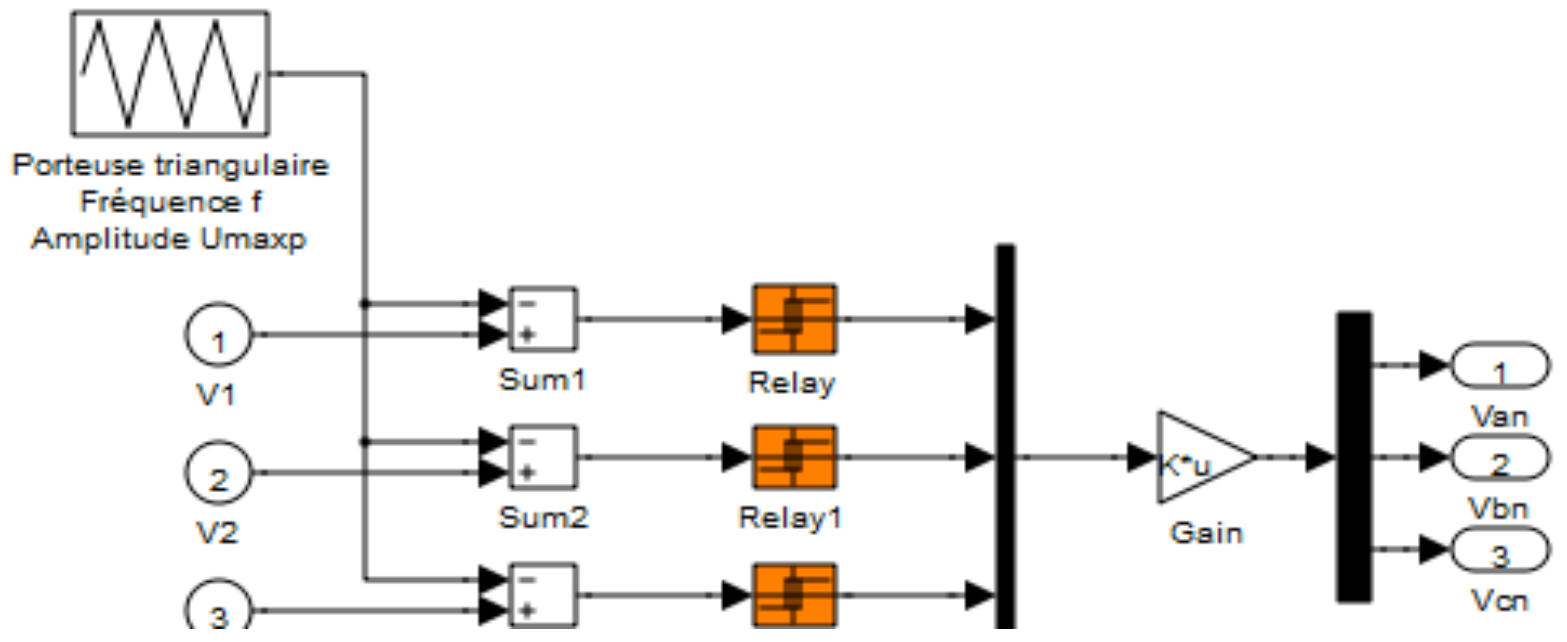

Fig. 1 PWM inverter.

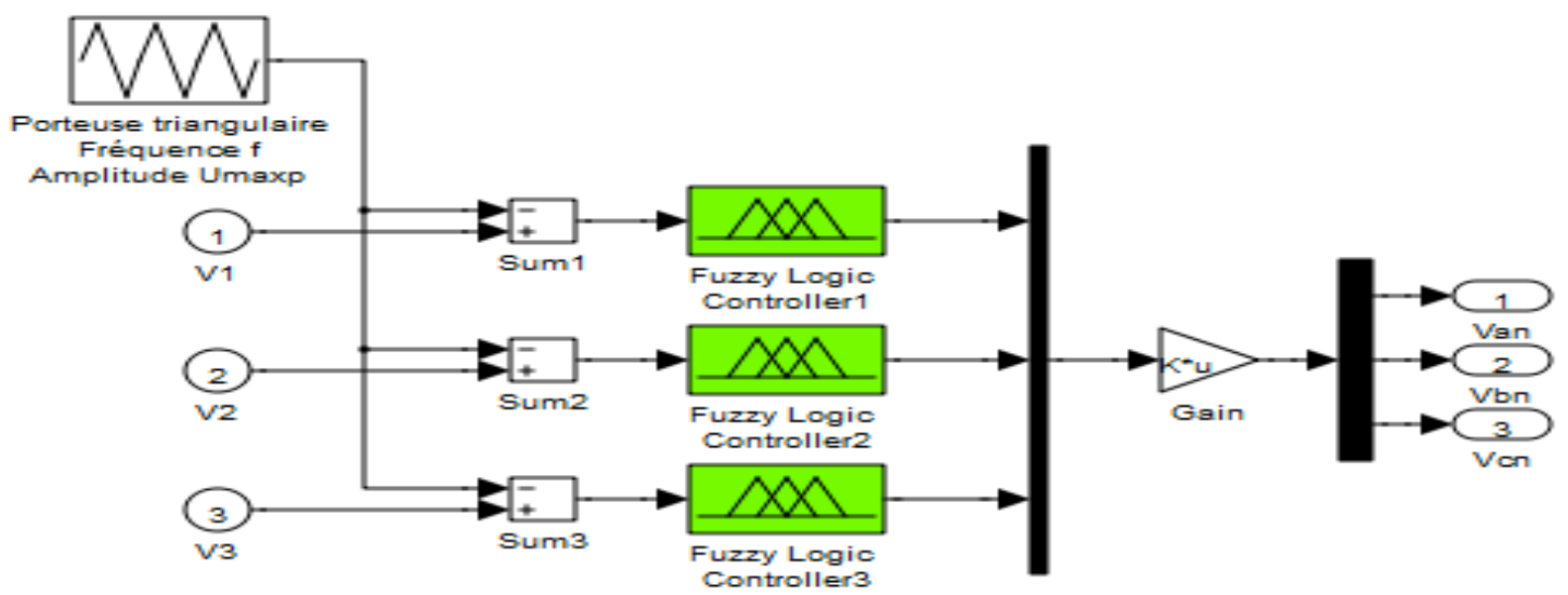

Fig. 2 FPWM inverter. 


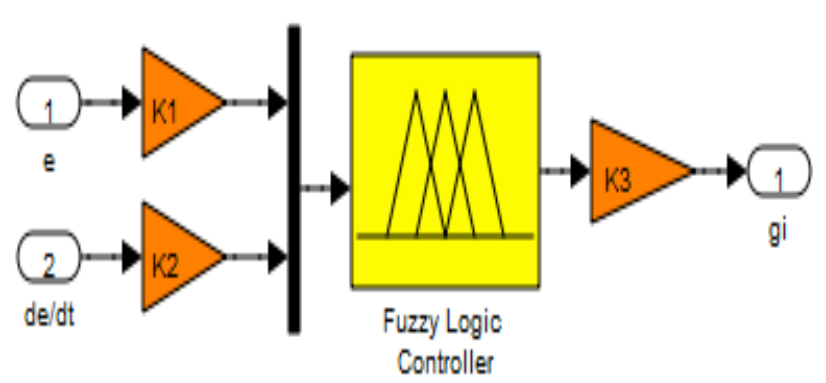

Fig. 3 Fuzzy command of PWM inverter.

On the other hand, the FL rules are developed using linguistic changes that are formulated in the form of « IF THEN » rules. The Table 1 shows this rules [20, 21].We use the following designations for membership functions:

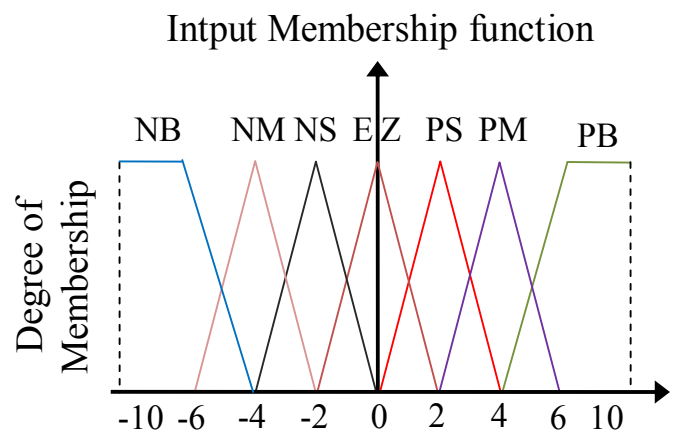

Fig. 4 Fuzzy sets and its memberships functions.

Table 1. Matrix of Inference

\begin{tabular}{|l|l|l|l|l|l|l|l|}
\hline \multicolumn{1}{|c|}{$\mathbf{e}$} & NB & NM & NS & EZ & PS & PM & PB \\
\cline { 1 - 6 } \multicolumn{1}{|c|}{} & & & & & & & \\
\hline NB & NB & NB & NB & NB & NM & NS & EZ \\
\hline NM & NB & NB & NB & NM & NS & EZ & PS \\
\hline NS & NB & NB & NM & NS & EZ & PS & PM \\
\hline EZ & NB & NM & NS & EZ & PS & PM & PB \\
\hline PS & NM & NS & EZ & PS & PM & PB & PB \\
\hline PM & NS & EZ & PS & PM & PB & PB & PB \\
\hline PB & EZ & PS & PM & PB & PB & PB & PB \\
\hline
\end{tabular}

The Table 2 shows the parameters of FL controller for PWM inverter.

Table 2. Parameters of fuzzy regulator

\begin{tabular}{|l|c|}
\hline Fis type & Mamdani \\
\hline And method & Min \\
\hline Or method & Max \\
\hline Implication & Min \\
\hline Aggregation & Max \\
\hline Defuzzification & Centroid \\
\hline
\end{tabular}

NB: Negative Big

NS: Negative Small

PB: Positive Big

PM: Positive Middle

PS: Positive Small

EZ: Equal Zero

NM: Negative Middle

Output Membership function

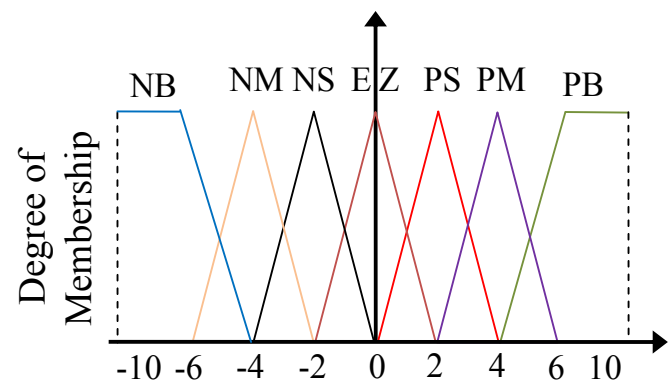

The electromagnetic torque is expressed as: 


$$
\begin{aligned}
& T_{e}=p M\left(I_{d r} \cdot I_{q s}-I_{q r} . I_{d s}\right) \\
& T_{e}=T_{r}+J \cdot \frac{d \Omega}{d t}+f \cdot \Omega
\end{aligned}
$$

The reactive and active powers at the stator can be expressed as:

$$
\left\{\begin{array}{l}
P_{s}=\frac{3}{2}\left(V_{d s} I_{d s}+V_{q s} I_{q s}\right) \\
Q_{s}=\frac{3}{2}\left(V_{q s} I_{d s}-V_{d s} I_{q s}\right)
\end{array}\right.
$$

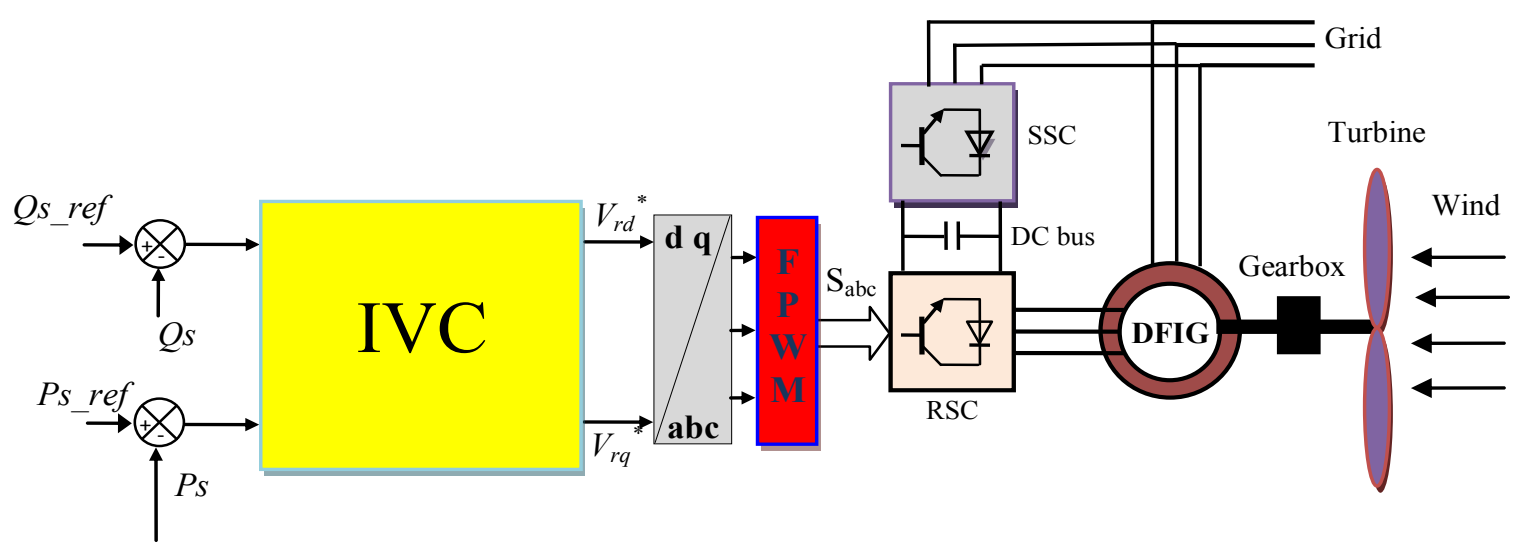

Fig. 5 Structure of IVC-FPWM command.

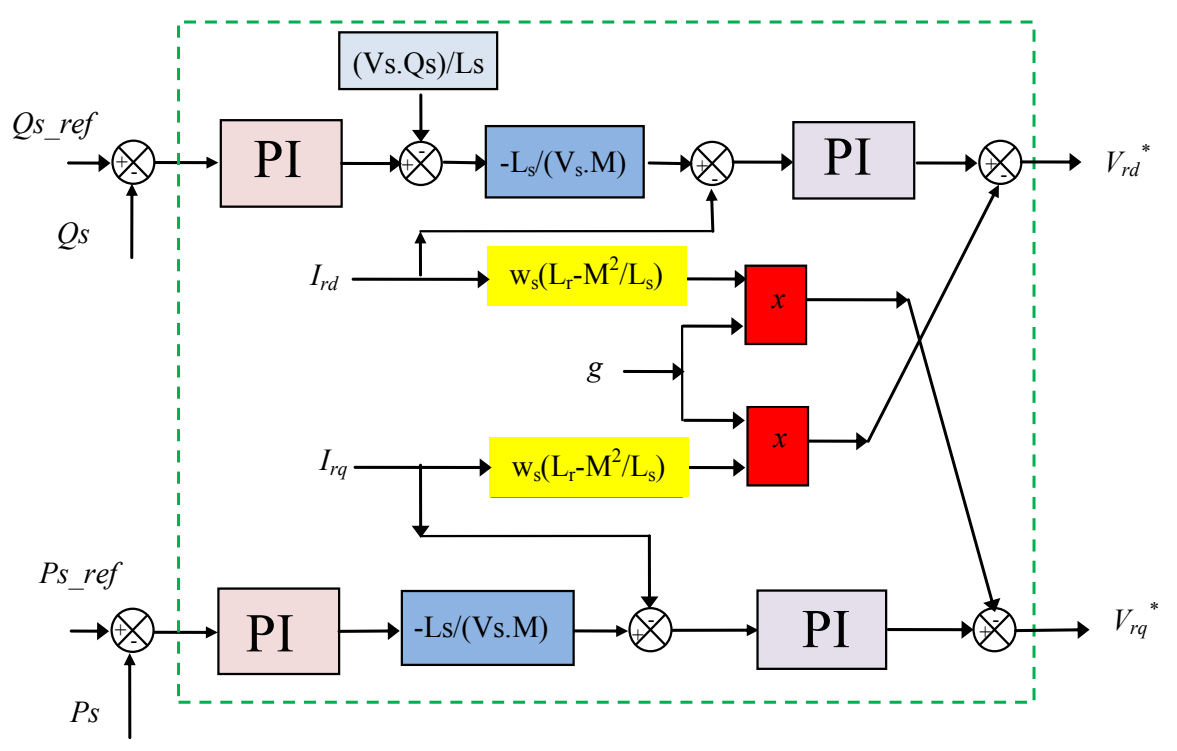

Fig. 6 Structure of IVC scheme. 


\section{Simulation Results}

Simulation of the proposed command techniques for a doubly fed induction generator is conducted by using the Matlab/Simulink package. The doubly fed induction generator is connected to a $398 \mathrm{~V} / 50 \mathrm{~Hz}$ grid. On the other hand, the doubly fed induction generator is rated at $1.5 \mathrm{MW}$, and its parameters are listed in Table 3. The both command strategies IVC-PWM and IVC-FPWM are simulated and compared in terms of current harmonics distortion, reference tracking, powers ripples and robustness against DFIG parameter variations.

Table 3. The DFIG parameters

\begin{tabular}{|l|c|c|}
\hline Parameters & Rated Value & Unity \\
\hline Nominal power & 1.5 & $\mathrm{MW}$ \\
\hline Stator voltage & 398 & $\mathrm{~V}$ \\
\hline Stator frequency & 50 & $\mathrm{~Hz}$ \\
\hline Number of pairs & 2 & \\
\hline Stator resistance & 0.012 & $\Omega$ \\
\hline Rotor resistance & 0.021 & $\Omega$ \\
\hline Stator inductance & 0.0137 & $\mathrm{H}$ \\
\hline Rotor inductance & 0.0136 & $\mathrm{H}$ \\
\hline Mutual inductance & 0.0135 & $\mathrm{H}$ \\
\hline Inertia & 1000 & $\mathrm{Kg} \mathrm{m}$ \\
\hline Viscous friction & 0.0024 & $\mathrm{Nm} / \mathrm{s}$ \\
\hline
\end{tabular}

\subsection{Reference Tracking Test}

Figs. 7-11 show the obtained simulation results for tracking test of the DFIG machine. As it's shown by Figs. 79, for the two proposed commands, the reactive and active powers tracks almost perfectly their references values, but with better transient response time in the case of the IVCFPWM command scheme. On the other hand, Figs. 10-11 show the harmonic spectrums of current of the doubly fed induction generator obtained using Fast Fourier Transform (FFT) method for both proposed command schemes. It can be clearly observed that the THD is reduced for IVC-FPWM command scheme. Table 4 shows the comparative analysis of the THD value of stator current for proposed commands scheme.

Table 4. Comparative analysis of THD value

\begin{tabular}{|l|c|c|}
\cline { 2 - 3 } \multicolumn{1}{c|}{} & \multicolumn{2}{c|}{ THD (\%) } \\
\cline { 2 - 3 } \multicolumn{1}{c|}{} & IVC-PWM & IVC-FPWM \\
\hline Stator current & 0.83 & 0.08 \\
\hline
\end{tabular}

Figs. 12-14 show the zoom in the reactive power, active power, and torque of the IVC-PWM and IVC-FPWM controls schemes. This figure shows that the ripple of reactive, active powers and torque in the IVC-PWM command scheme has been zero compared with the IVCPWM command. It is clear from the results that the FPWM inverter has satisfied performance.

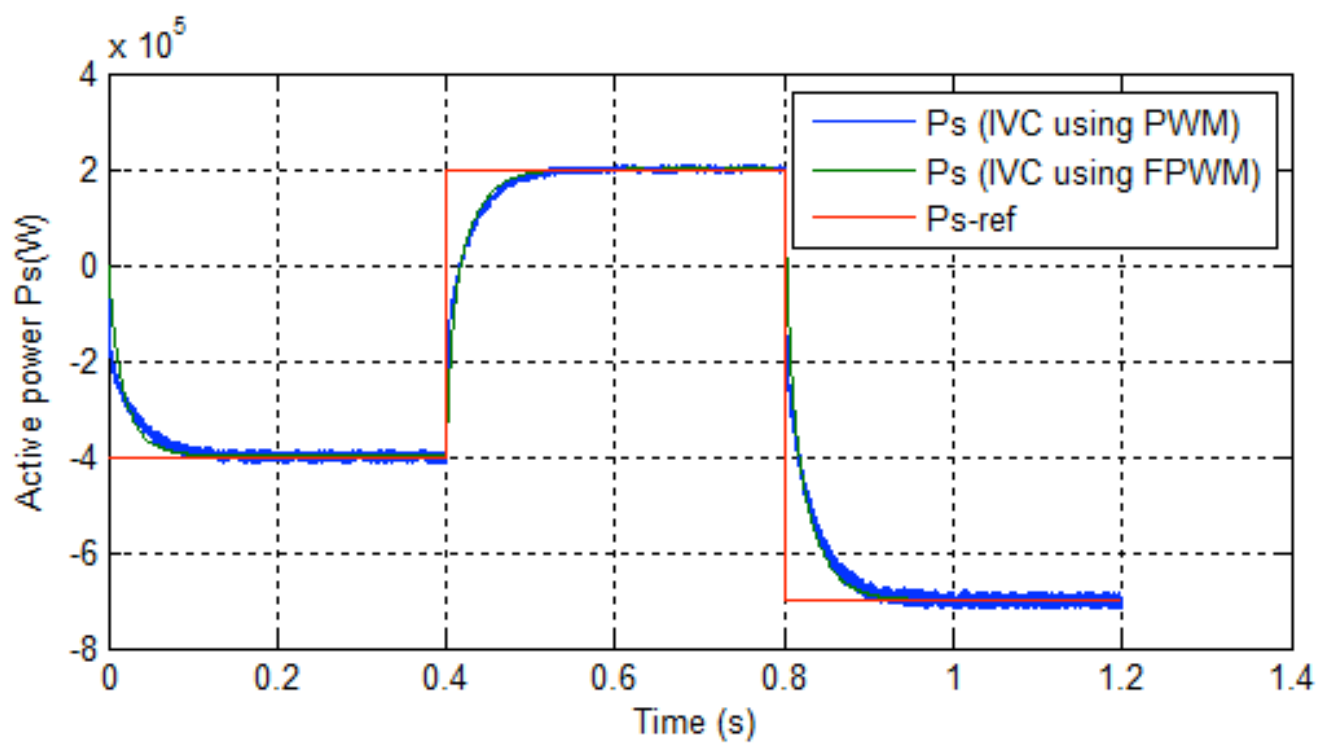

Fig. 7 Stator active energy. 
INTERNATIONAL JOURNAL Of SMART GRID

H.Benbouhenni et al., Vol.2, No.3, 2018

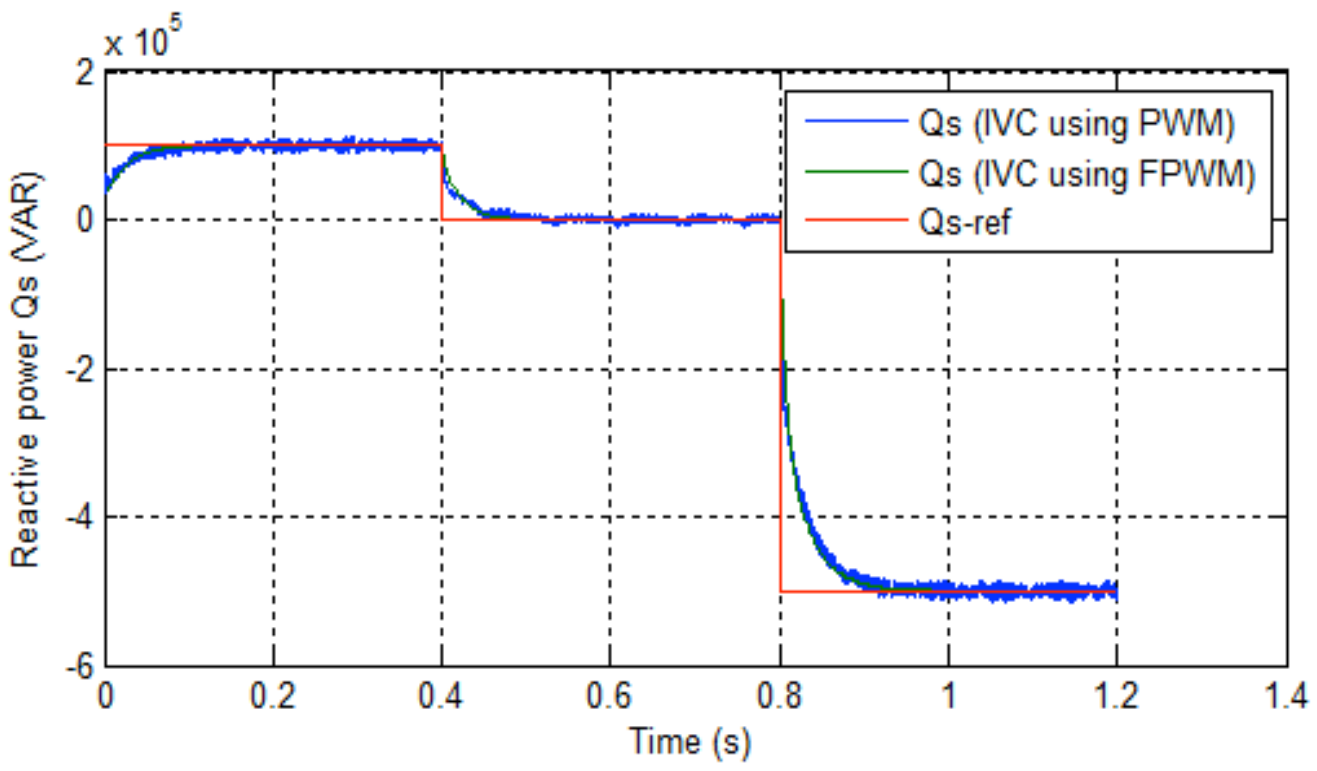

Fig. 8 Stator reactive energy.

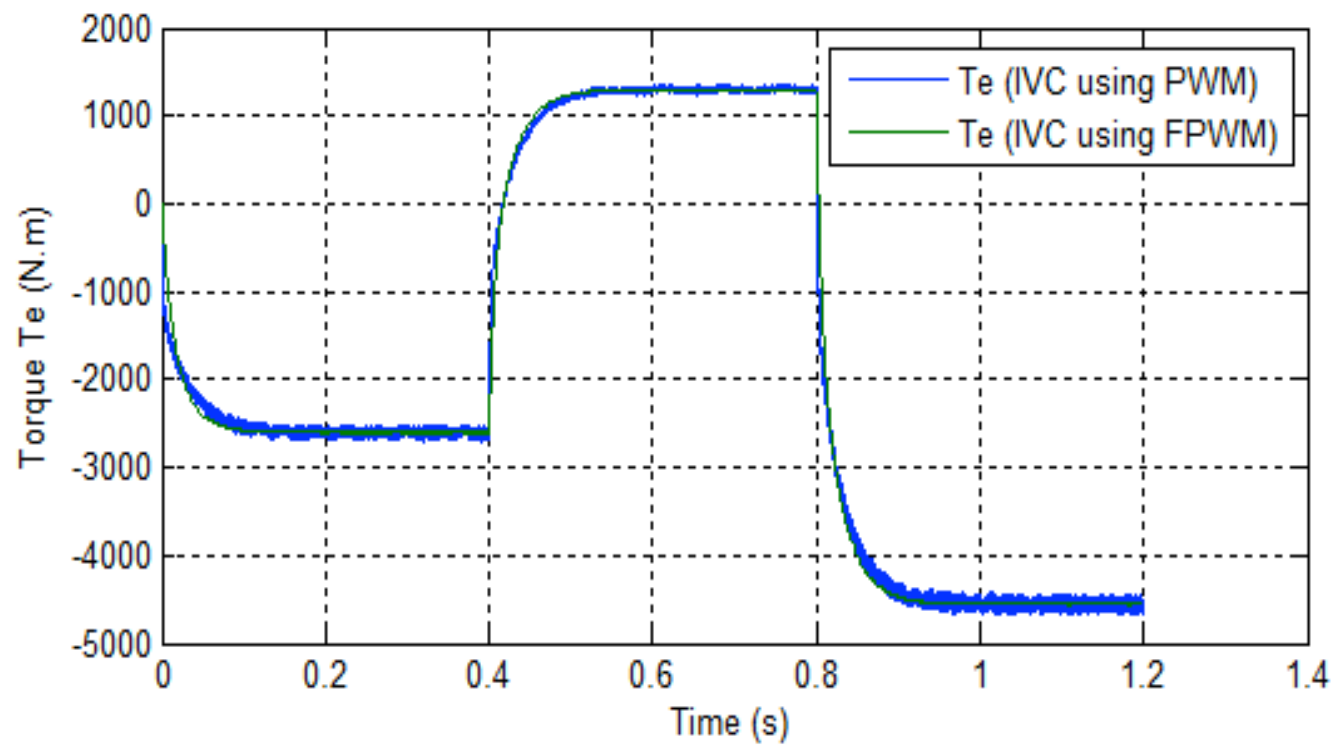

Fig. 9 Electromagnetic torque. 

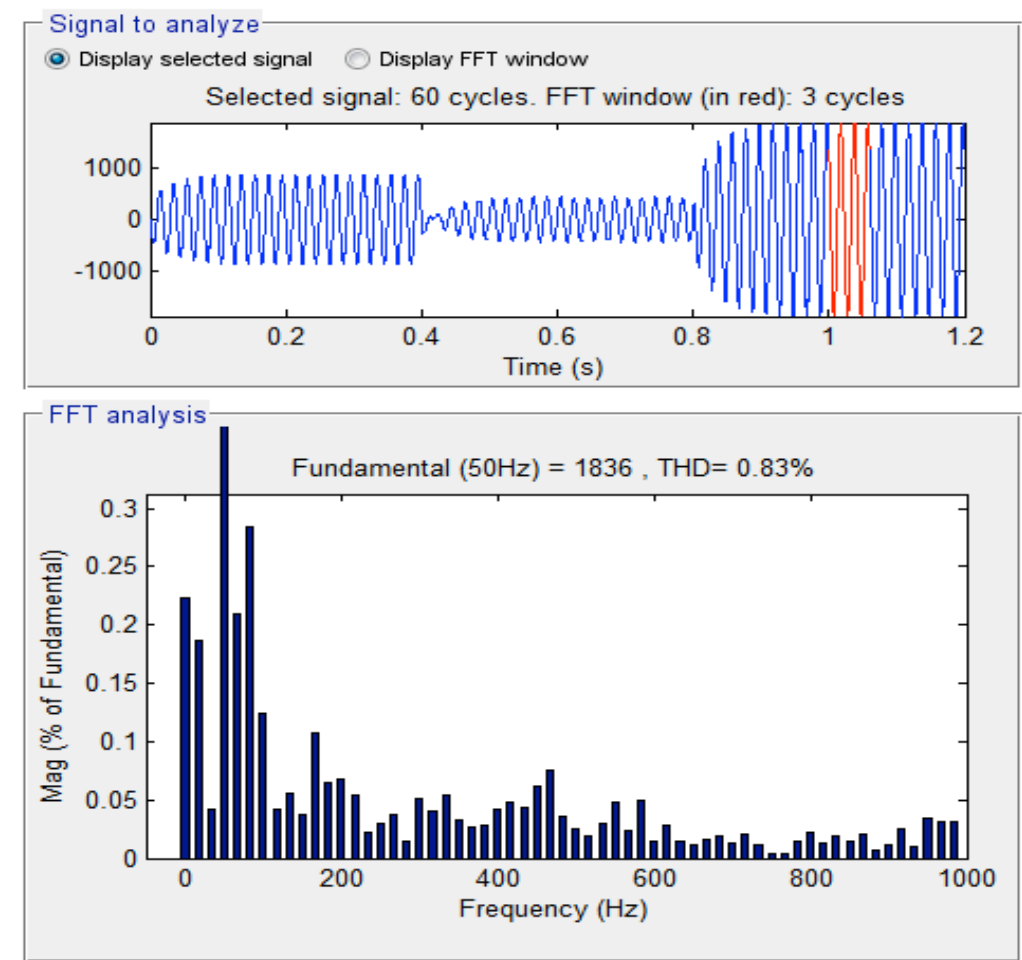

Fig. 10 THD of one phase current for a doubly fed induction generator (IVC-PWM).
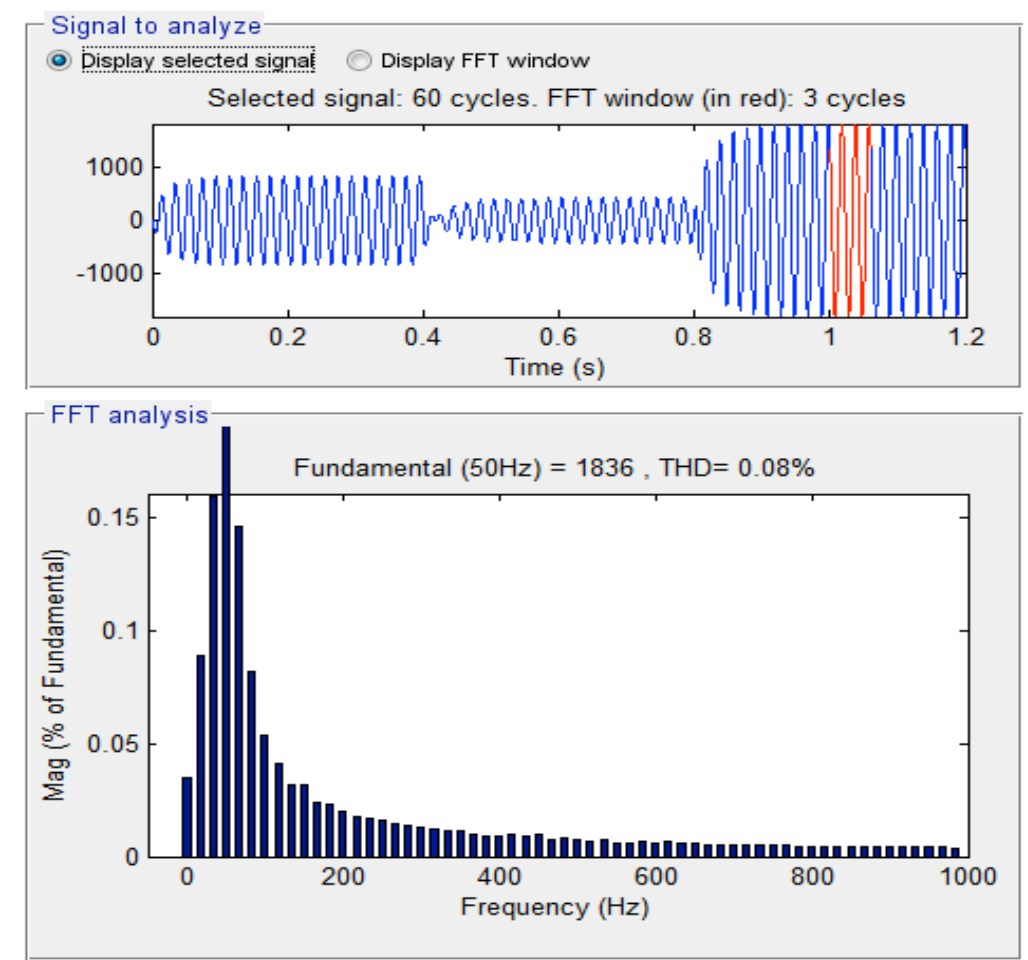

Fig. 11 THD of one phase current for a doubly fed induction generator (IVC-FPWM). 


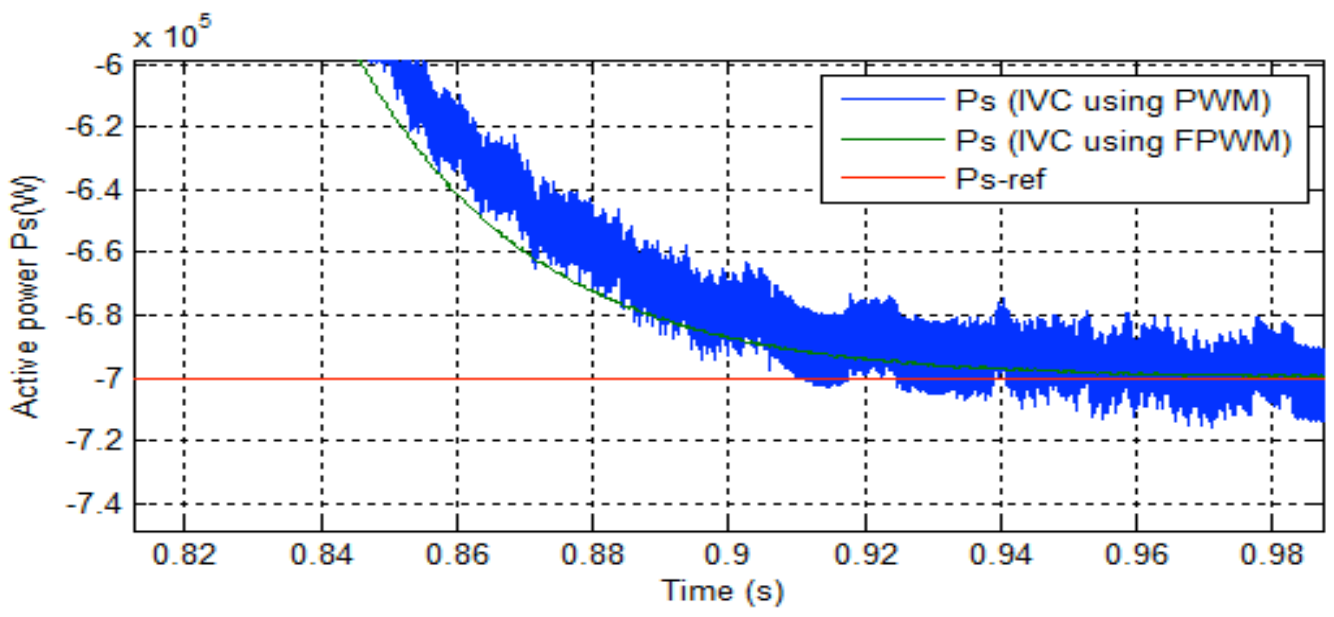

Fig. 12 Zoom in the active power (reference tracking test).

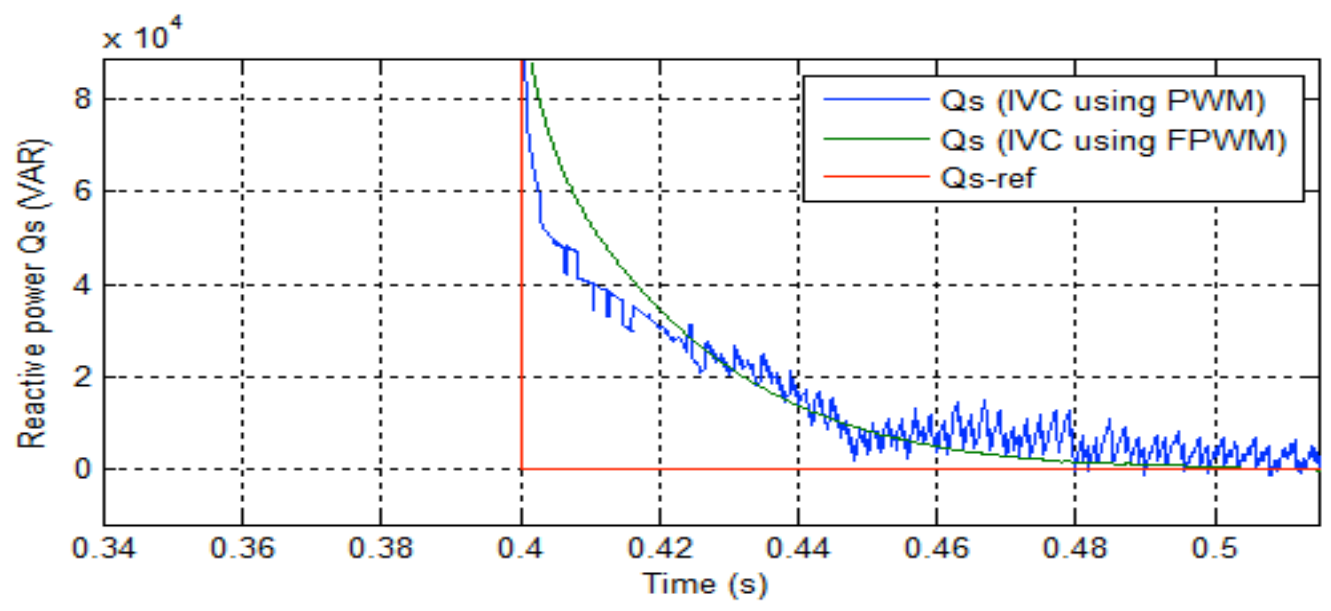

Fig. 13 Zoom in the stator reactive power (reference tracking test).

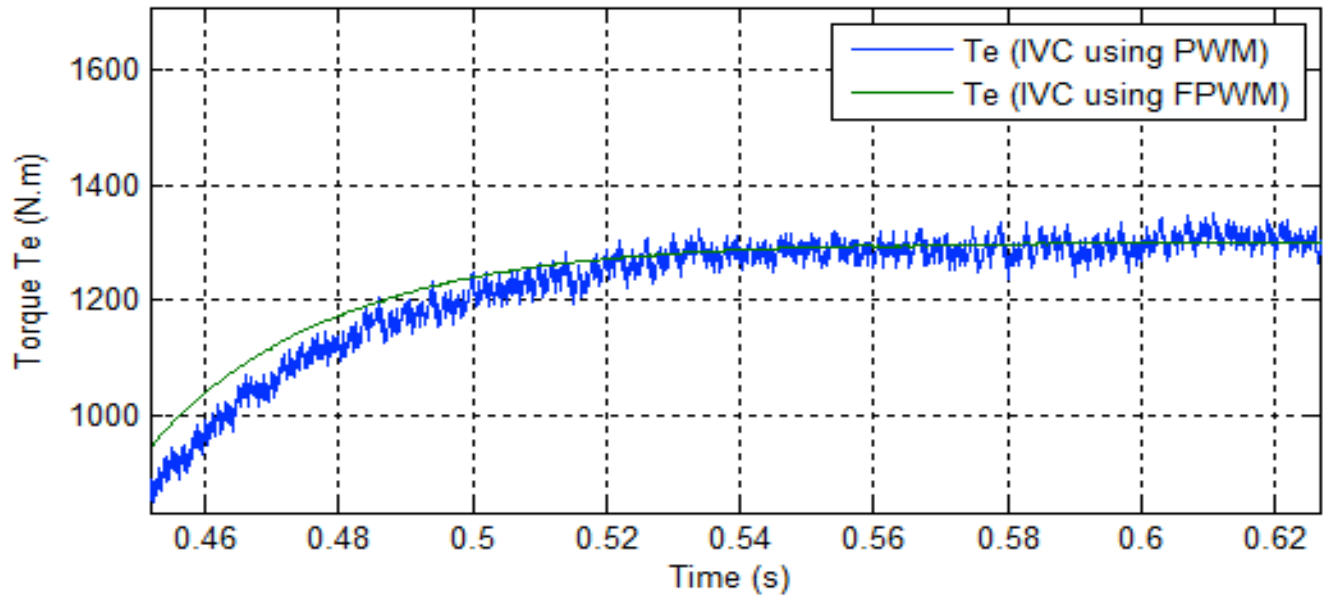

Fig. 14 Zoom in the torque (reference tracking test). 


\subsection{Robustness test}

In order to investigate the robustness of the proposed controls schemes of the DFIG machine, the nominal value of the $\mathrm{R}_{\mathrm{r}}$ and $R_{s}$ is multiplied by 2 , the values of inductances $L_{s}$, $\mathrm{M}$, and $\mathrm{L}_{\mathrm{r}}$ are multiplied by 0.5 . Simulation results are presented in Figs 15-17. As it's shown by these Figures, these variations present a clear effect on the stator active, stator reactive power, and torque curves and that the effect appears more and more important for the IVC-PWM command scheme. On the other hand, these results show that the THD value of stator current in the IVC-FPWM command scheme has been reduced significantly. Table 5 shows the comparative analysis of THD value. Thus it can be concluded that the proposed IVC using FPWM command scheme is more and more robust than the IVC using PWM one.
Table 5. Comparative analysis of THD value

\begin{tabular}{|l|c|c|}
\cline { 2 - 3 } \multicolumn{1}{c|}{} & \multicolumn{2}{c|}{ THD (\%) } \\
\cline { 2 - 3 } \multicolumn{1}{c|}{} & IVC-PWM & IVC-FPWM \\
\hline Stator current & 2.46 & $\mathbf{0 . 1 0}$ \\
\hline
\end{tabular}

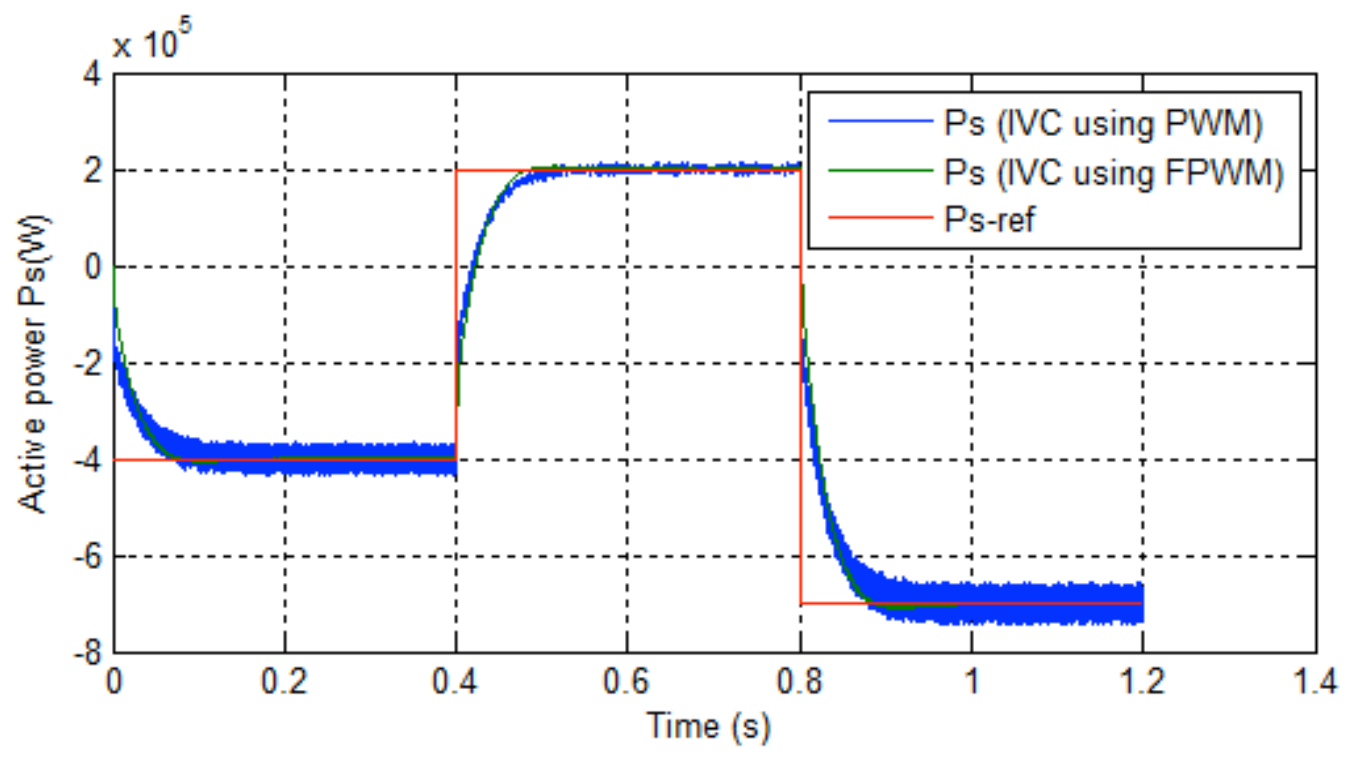

Fig. 15 Stator active power.

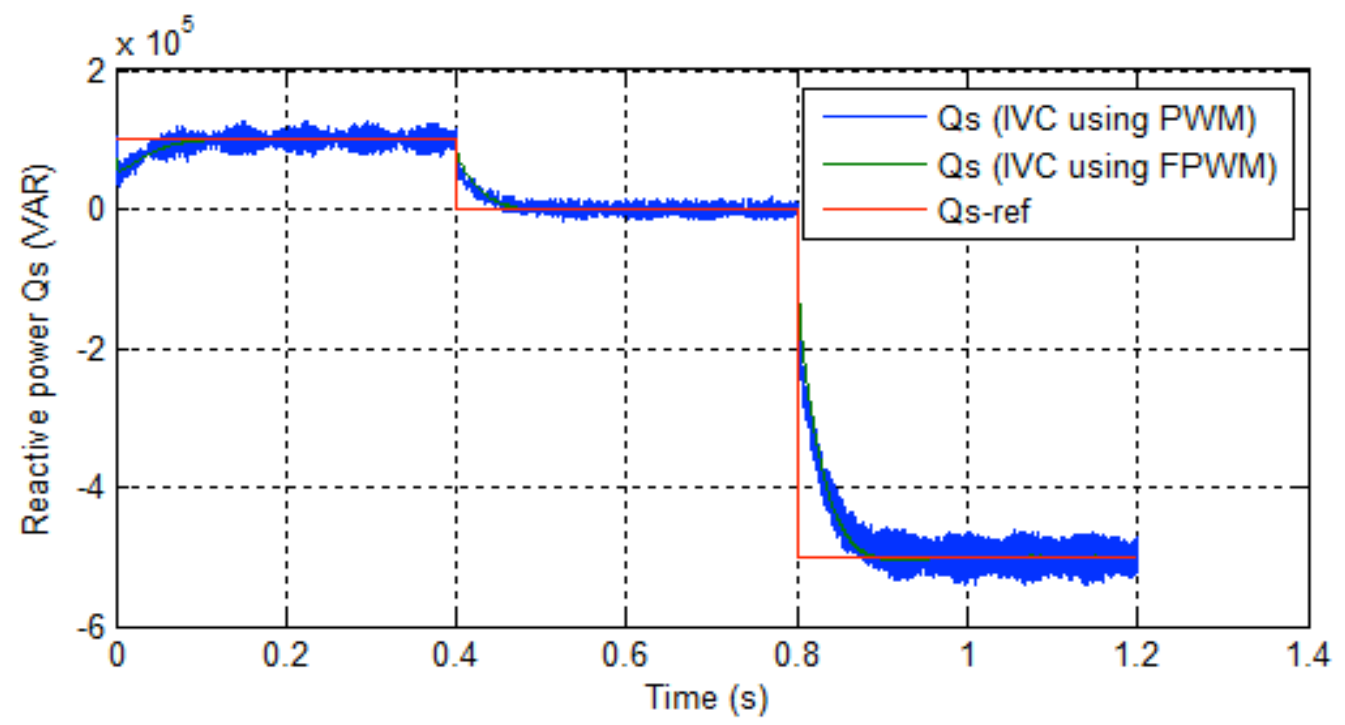

Fig. 16 Stator reactive power. 


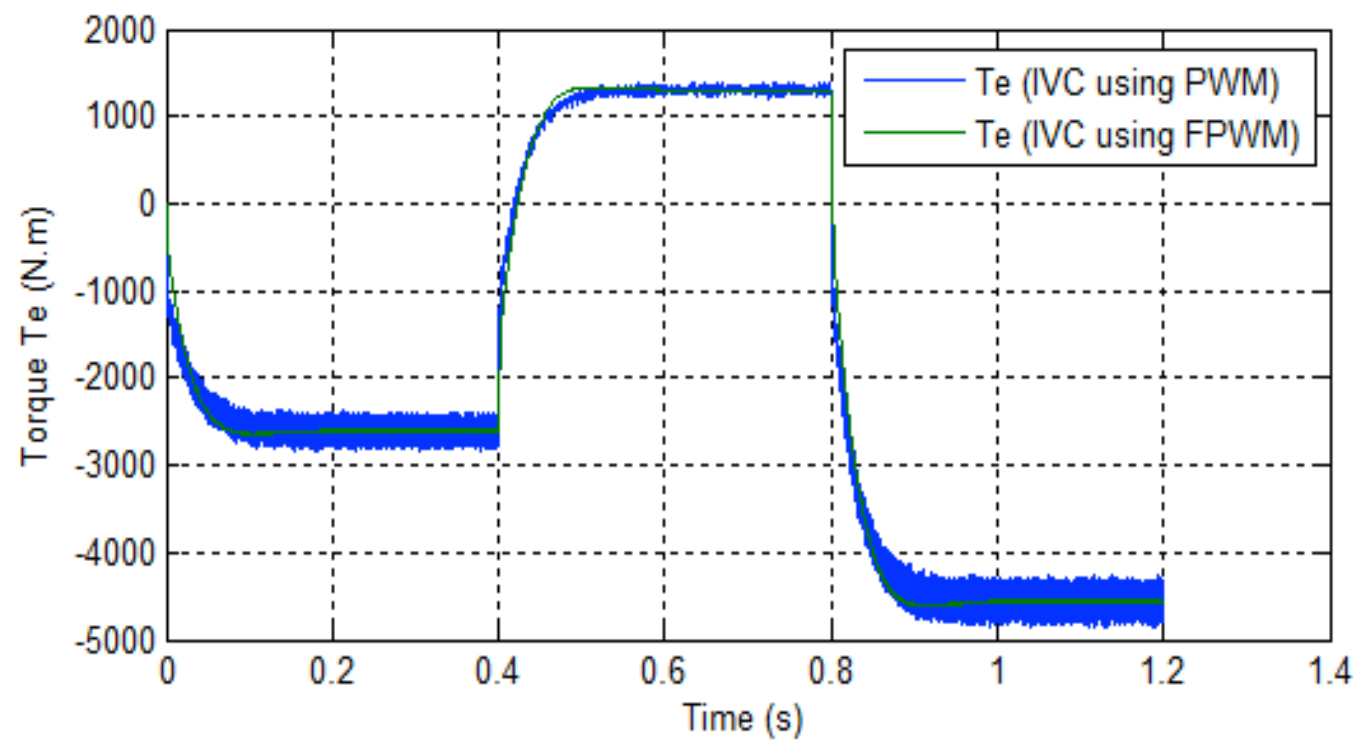

Fig. 17 Electromagnetic torque.
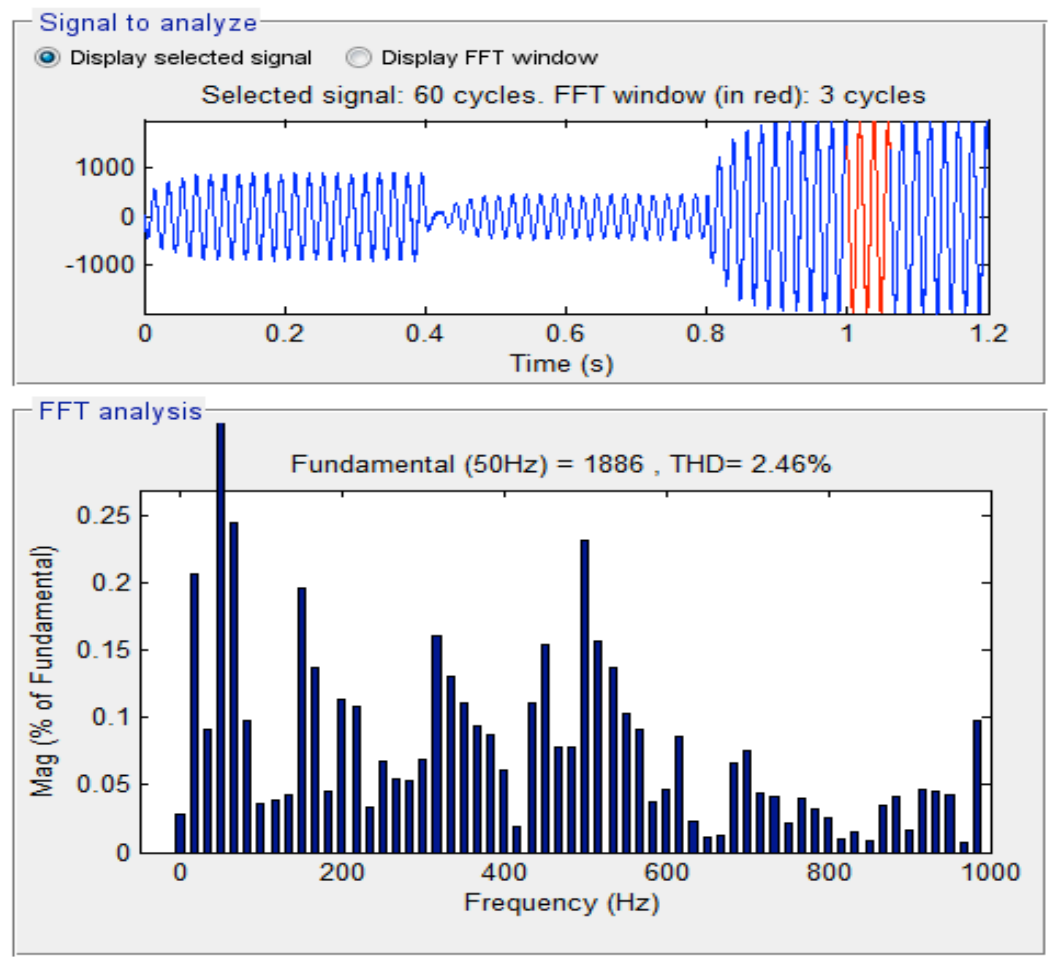

Fig. 18 THD of one phase current for a doubly fed induction generator (IVC-PWM). 
INTERNATIONAL JOURNAL Of SMART GRID

H.Benbouhenni et al., Vol.2, No.3, 2018
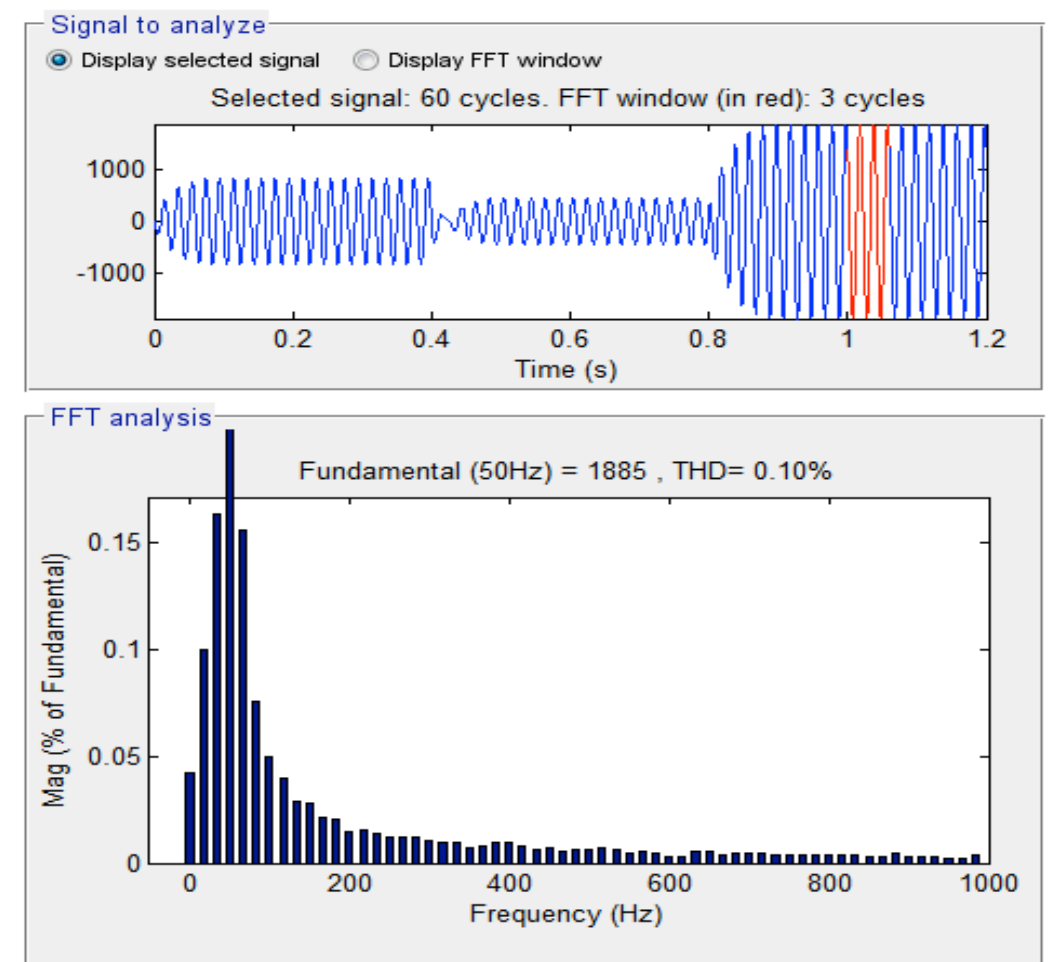

Fig. 19 THD of one phase current for a doubly fed induction generator (IVC-FPWM).

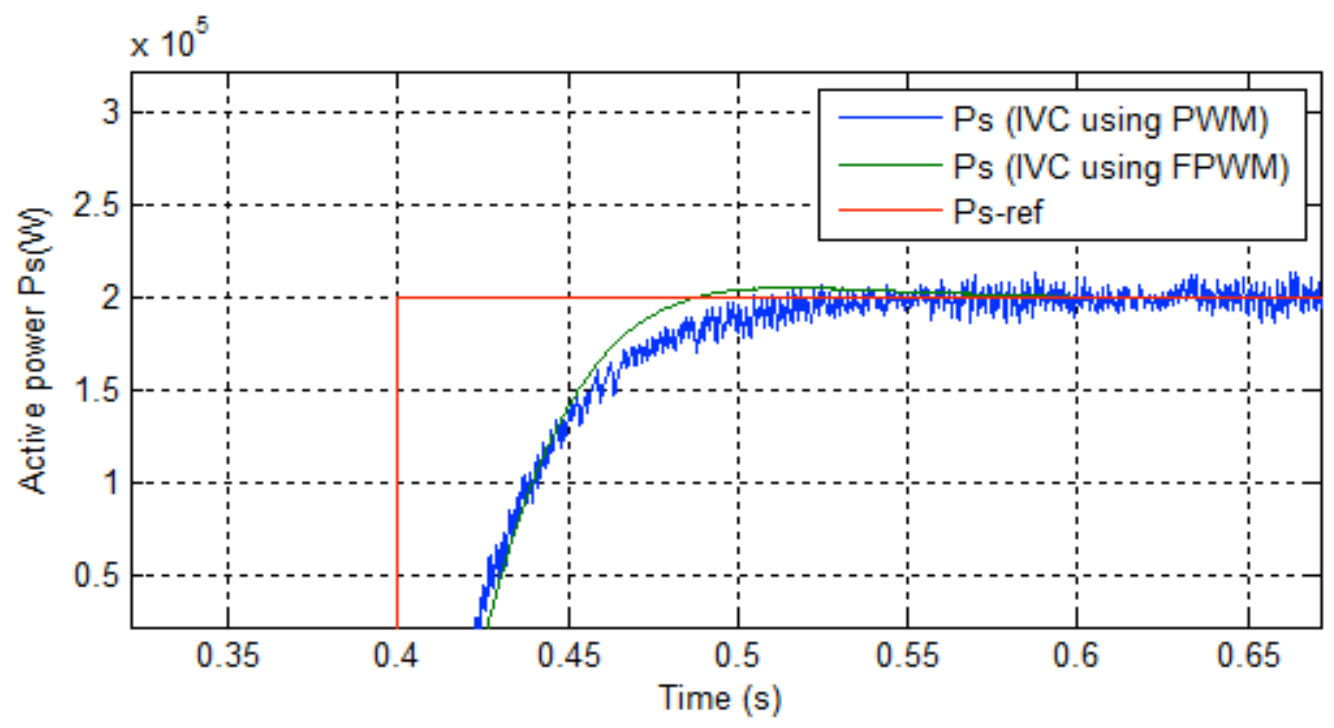

Fig. 20 Zoom in the stator active power (robustness test). 


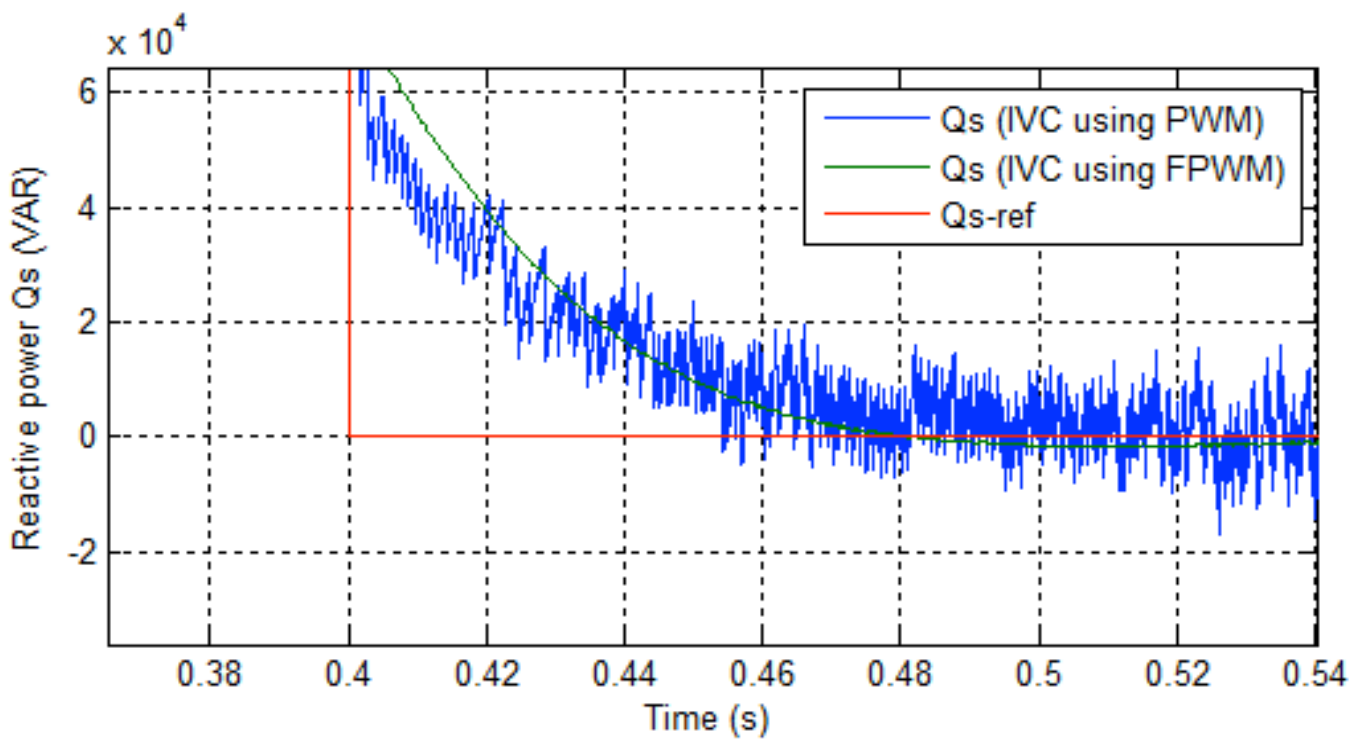

Fig. 21 Zoom in the stator reactive power (robustness test).

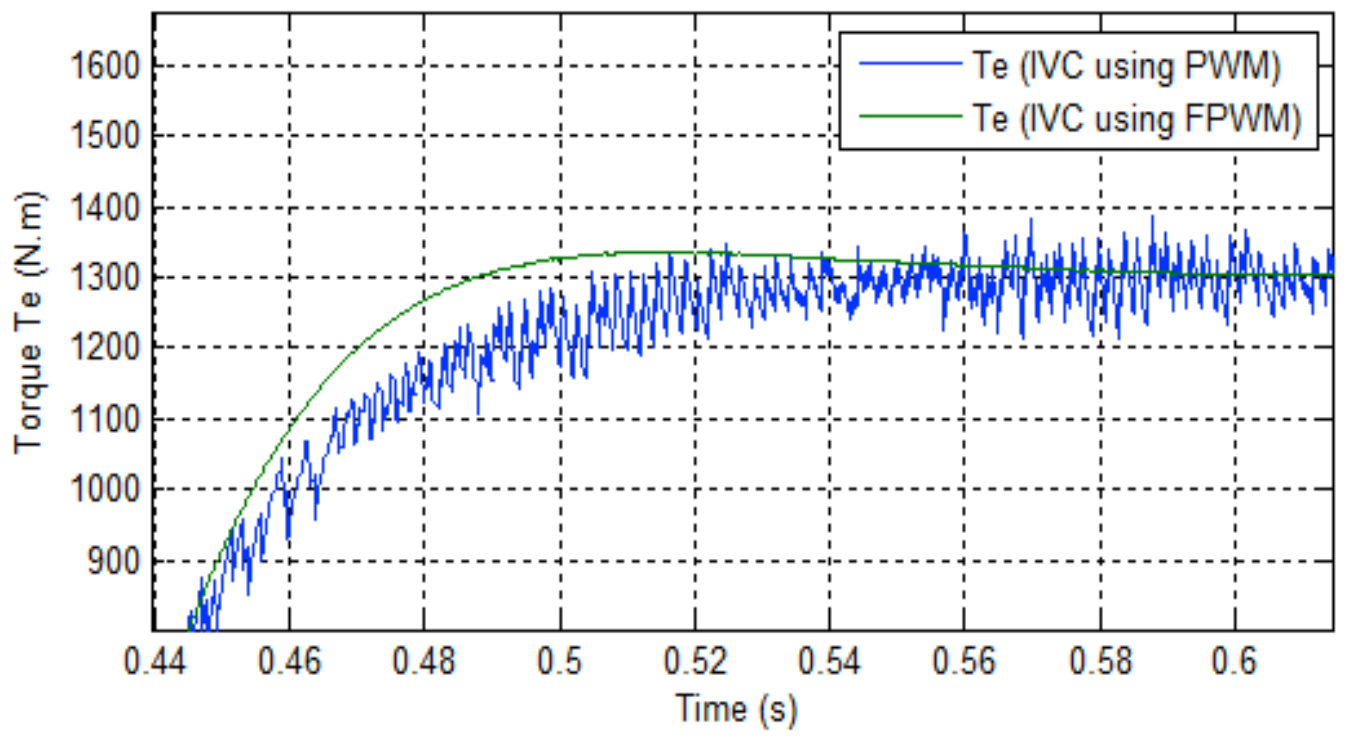

Fig. 22 Zoom in the torque (robustness test).

\section{Conclusion}

This work presents simulation results of indirect vector command for stator reactive power and active power command of the doubly fed induction generator, using the modulation technique of the FPWM and classical PWM strategy. With results obtained from simulation, it is clear that for the same operation condition, the doubly fed induction generator reactive power and stator active power command with IVC using FPWM inverter had better performance than the conventional PWM strategy and that is clear in the spectrum of one phase current harmonics which the use of the FPWM strategy, it is reduced of THD more and more than conventional pulse width modulation strategy.

\section{References}

[1] Y. Bekakra, D. Ben Attous, « Comparison study between SVM and PWM inverter in sliding mode control of active and reactive power control of a DFIG for variable speed wind energy, » International Journal of Renewable Energy Research, Vol. 2, No.3, pp. 471-776, 2012.

[2] S. Massoum, A. Meroufel, A. Massoum, P. Wira, «A direct power control of the doubly-fed induction 
generator based on the SVM strategy, » Elektrotehniski Vestnik, Vol. 45, No. 5, pp. 235-240, 2017.

[3] M. Gaballah, M. El-Bardini, «Low cost digital signal generation for driving space vector PWM inverter, " Ain Shams Engineering Journal, Vol. 4, pp. 763-774, 2013.

[4] A. Kavousi, B. Vahidi, R. Salehi, M. K. Bakhshizadah, N. Forokhnia, S. H. Fathi, «Application of the bee algorithm for selective harmonic elimination strategy in multilevel inverter, " IEEE transactions on power Electronics, Vol. 27, No.4, pp. 1689-1696, 2012.

[5] F. Chabni, R. Taleb, M. Helaimi, «Differential evolution based SHEPWM for seven-level inverter with non-equal DC source, " International Journal of Advanced Computer Science and Applications, Vol. 7, No. 9, pp. 304-311, 2016.

[6] Z. B. Ibrahim, Md. L. Hossain, I. B. Bugis, N. M. N. Mahadi, A. S. Abu Hasim, "Simulation investigation of SPWM, THIPWM and SVPWM techniques for three phase voltage source inverter, " International Journal of Power Electronics and Drive System, Vol. 4, No. 2, pp. 223-232, 2014.

[7] L. Chaturvedi, D. K. Yadav, G. Pancholi, «Comparison of SPWM, THIPWM and PDPWM techniques based voltage source inverters for application in renewable energy, " Journal of Green Engineering , Vol. 7, pp. 83-98, 2017.

[8] J. Lyu, W. Hu, F. Wu, K. Yao, J. Wu, « A new DPWM method to suppress the low frequency oscillation of the neutral-point voltage for NPC three-level inverters, " Journal of Power Electronics, Vol. 15, No. 5, pp.1207-1216, 2015.

[9] C. Aghion, O. Ursaru, «Three-phase inverter controlled by ISCPWM and DPWM-S1, » Electronics and Electrical Engineering, Vol. 3, pp. 87-90, 2012.

[10] Y. Wu, W. Yang, «Different control strategies on the rotor side converter in DFIG-based wind turbine, » Energy Procedia, Vol. 100, pp. 551-555, 2016.

[11] E. G. Shehata, «Sliding mode direct power control of RSC for DFIGs driven by variable speed wind turbines, » Alexandria Engineering Journal, Vol. 54, pp. 1067-1075, 2015.

[12] Z. Boudjema, R. Taleb, Y. Djerriri, A. Yahdou, «A novel direct torque control using second order continuous sliding mode of a doubly fed induction generator for a wind energy conversion system, " Turkish Journal of Electrical Engineering \& Computer Sciences, Vol. 25, pp. 965-975, 2017.

[13] F. Amrane, A. Chaiba, «A novel direct power control for grid-connected doubly fed induction generator based on hybrid artificial intelligent control with space vector modulation, 》 Rev. Roum. Sci. Techn.-Electrotechn. Et Energ, Vol. 61, No.3, pp. 263-268, 2016.

[14] F. Amrane, A. Chaiba, B. Babas, S. Mekhilef, « Design and implementation of high performance field oriented control for grid-connected doubly fed induction generator via hysteresis rotor current controller, "Rev. Roum. Sci. Techn.-Electrotechn. Et Energ, Vol. 61, No.4, pp. 319-324, 2016.

[15] Z. Boudjema, A. Meroufel, A. Amari, « Robust control of a Doubly fed induction generator (DFIG) fed by a direct AC-AC converter, » Przegląd Elektrotechniczny, Vol. 11, pp. 213-221, 2012.

[16] M. El-Azzaoui, H. Mahmoudi, K. Boudaria, «Backstepping control of wind and photovoltaic hybrid renewable energy system, " International Journal of Power Electronics and Drive Systems, Vol. 7, No.3, pp. 677-686, 2016.

[17] A. Yahdou, B. Hemici, Z. Boudjema, «Second order sliding mode control of a dual-rotor wind turbine system by employing a matrix converter, " Journal of Electrical Engineering, Vol. 16, No.4, pp.1-11, 2016.

[18] M. Palanivelu, M. Duraisany, « Color textured image segmentation using ICICM-intervel type-2 fuzzy Cmeans clustering hybrid approach, ” Engineering Journal, Vol. 16, No. 5, pp. 115-126, 2012.

[19] R. Hendel, F. Khaber, N. Essounbouli, « Adaptive type2 fuzzy second order sliding mode control for nonlinear uncertain chaotic system, " International Journal of Computational Science, Information Technology and Control Engineering, Vol. 2, No.4, pp. 1-14, 2015.

[20] Z. Boudjema, R. Taleb, A. Yahdou, A. Bouyekni, «Fuzzy second order sliding mode control of a doublyfed induction machine supplied by to matrix converters, " Journal of Electrical Engineering, Vol. 15, No.3, pp. 1-10, 2015.

[21] A. Bakouri, H. Mahmoudi, A. Abbou, «Intelligent control for doubly fed induction generator connected to the electrical network, " International Journal of Power Electronics and Drive System, Vol. 7, No.3, pp. 688-700, 2016.

[22] E. Bounadja, A. Djahbar, Z. Boudjema, «Variable structure control of a doubly fed induction generator for wind energy conversion systems, ") Energy Procedia, Vol. 50, pp. 999-1007, 2014.

[23] M. Hasni, Z. Mancer, S. Mekhtoub, S. Bacha, «Parametric identification of the doubly fed induction machine, » Energy Procedia, Vol. 18, pp.177-186, 2012.

[24] F. Senani, A. Rahab, H. Benalla, «Modeling and control of active and reactive powers of wind energy conversion system in variable speed based on DFIG, » Revue des Energy Renouvelables, Vol. 18, No.4, pp. 643-655, 2015.

[25] K. Kerrouche, A. Mezouar, Kh. Belgacem, « Decoupled control of doubly fed induction generator by vector control for wind energy conversion system, " Energy Procedia, Vol. 42, pp. 239-248, 2013.

[26] A. Medjber, A. Moualdia, A. Mellit, M. A. Guessoum, "Comparative study between direct and indirect vector control applied to a wind turbine equipped with a doublefed asynchronous machine Article, » International Journal of Renewable Energy Research, Vol. 3, No. 1, pp. 88-93, 2013. 